\title{
Natural regeneration of tree species in the understory of Corymbia citriodora in Florestal city, Minas Gerais, Brazil
}

\author{
Laís Alvares Fonseca*, Francisco de Assis Braga, Geanderson Santiago Fernandes \\ Universidade Federal de Viçosa, Florestal, 35.690-000, Minas Gerais, Brazil. *laisalvares.ufv@gmail.com
}

Received: August 14, 2019 / Accepted: September 7, 2019 / Published online: September 30, 2019

\begin{abstract}
The natural regeneration of tree species in forested areas has been studied by several researches. This study aimed to evaluate the natural regeneration of tree species in Corymbia citriodora (Hook.) K. D. Hill \& L. A. Johnson planted forest understory in Florestal, Minas Gerais, Brazil. Individuals with diameter at breast height (DBH) $\geq 5 \mathrm{~cm}$ were evaluated in seven $25 \times 4 \mathrm{~m}$ plots randomly distributed. A phytosociological survey was carried out and the ecological groups and the dispersal syndromes of the regenerants were determined. We found 28 species belonging to 12 families, among which Fabacea and Annonaceae stood out. Density was 1,557 regenerants ha- ${ }^{-1}$, and basal area was $23 \mathrm{~m}^{2}$ ha $^{-1}$. The most important species were Psidium sp; Schefflera macrocarpa (Cham. \& Schltdl.) Frodin; Pera glabrata (Schott) Poepp. ex Baill.; Astronium fraxinifolium Schott \& Spreng.; Matayba guianensis Aubl.; and Plathymenia reticulata Benth. We found 35\% pioneer, $40 \%$ early secondary, $18 \%$ late secondary, and $7 \%$ climax species, of which $57 \%$ are zoochoric, $40 \%$ anemochoric, and $3 \%$ autochoric. It is concluded that the natural regeneration in the understory studied comprises typical species of the Seasonal Semideciduous Forest of the Atlantic Forest biome, presenting significant density and individuals from all ecological groups.
\end{abstract}

Keywords: Degraded area recovery, forest restoration, forest succession.

\section{Regeneração natural de espécies arbóreas no sub-bosque de Corymbia citriodora no município de Florestal, Minas Gerais, Brasil}

\begin{abstract}
Resumo
A regeneração natural de espécies arbóreas em áreas com plantios florestais tem sido estudada por diversas pesquisas. Este estudo objetivou avaliar a regeneração natural de espécies arbóreas no sub-bosque de floresta plantada de Corymbia citriodora (Hook.) K. D. Hill \& L. A. Johnson em Florestal, Minas Gerais, Brasil. Foram avaliados os indivíduos com diâmetro a altura do peito DAP $\geq 5 \mathrm{~cm}$, em sete parcelas de $25 \mathrm{x} 4 \mathrm{~m}$, lançadas ao acaso. Elaborou-se estudo fitossociológico e determinou-se os grupos ecológicos e as síndromes de dispersão das regenerantes. Foram encontradas 28 espécies, pertencentes a 12 famílias, com destaque para Fabacea e Annonaceae. A densidade foi de 1.557 indivíduos regenerantes ha ${ }^{-1} \mathrm{e}$ a área basal de $23 \mathrm{~m}^{2} \mathrm{ha}^{-1}$. As espécies de maior importância foram Psidium sp; Schefflera macrocarpa (Cham. \& Schltdl.) Frodin; Pera glabrata (Schott) Poepp. ex Baill.; Astronium fraxinifolium Schott \& Spreng.; Matayba guianensis Aubl. e Plathymenia reticulata Benth. Foram encontradas 35\% de pioneiras, $40 \%$ secundárias iniciais, $18 \%$ secundárias tardias e 7\% climácicas; sendo 57\% zoocóricas, $40 \%$ anemocóricas e 3\% autocóricas. Conclui-se que na regeneração natural no sub-bosque em estudo foram encontradas espécies típicas da tipologia Floresta Estacional Semidecidual do bioma Mata Atlântica, apresentando significante densidade e indivíduos de todos os grupos ecológicos.
\end{abstract}

Palavras-chave: Recuperação de áreas degradadas, restauração florestal, sucessão florestal.

\section{Introduction}

Despite its worldwide ecological and environmental relevance, the Atlantic Forest biome occupies only $11 \%$ to $16 \%$ of its original area, consisting now of small and isolated remnant fragments, of which $80 \%$ are smaller than 50 ha and distant, on average, $1,440 \mathrm{~m}$ apart (Ribeiro, Metzger, Martensen, Ponzoni, \& Hirota, 2009).

This condition can greatly hinder the forest restoration process, given the limitations imposed on seed dispersal by wind or fauna, the low permeability of the landscape matrix, and the poor conservation status of the remaining fragments (Viani, Durigan, \& Melo, 2010). In this context, forest restoration practices require a combination of local- and landscape-scale approaches, as both are crucial in the natural regeneration process (Souza Leite, Tambosi, Romitelli, \& Metzger, 2013).

In the case of tropical and subtropical forests, the restoration process involves the structuring, consolidation, and maturation stages (Brancalion, Gandolfi \& Rodrigues, 
2015). The initial and structuring phase consists of the formation of a canopy and a shaded forest habitat, enabling conditions for the contribution and gradual establishment of understory tree species, accompanied by the progressive elimination of invasive and competing species that may be present in the area (Gandolfi, 2017).

Possibilities for structuring the initial forest canopy include planting homogeneous forests, notably eucalyptus ones, provided that they allow the establishment of natural regeneration of native species at a satisfactory level in their understory (Carneiro \& Rodrigues, 2007; Isernhagen, Rodrigues, Nave, \& Gandolfi, 2009).

Studies show that homogeneous forest plantations can act as catalysts for secondary forest succession, facilitating the natural regeneration of native vegetation by favoring the entry, germination, and establishment of tree species in the understory as long as there is landscape resilience that can act as an allochthonous source of propagules (Viani et al., 2010).

This research evaluated the natural regeneration of tree species in the understory of a planted forest of $C$. citriodora in Florestal city, Minas Gerais, Brazil.

\section{Materials and Methods}

\section{Study area}

The study was conducted at the Federal University of Viçosa - Campus Florestal, in Florestal city, Minas Gerais, Brazil. The area has about 0.5 ha of C. citriodora forest, planted about 60 years ago at a spacing of $3 \times 3 \mathrm{~m}$. It is located at coordinates $19^{\circ} 53^{\prime} 05.39^{\prime \prime} \mathrm{S}$ and $44^{\circ} 25^{\prime} 28.15^{\prime \prime} \mathrm{W}$, at an altitude of $781 \mathrm{~m}$. The current density of planted C. citriodora trees remaining in the area is about 125 individuals.

The relief is characterized as $9 \%$ flat, $54 \%$ wavy, and $17 \%$ mountainous, with altitudes between 684 and $1,158 \mathrm{~m}$. The Economic Ecological Zoning of Minas Gerais classifies the vegetation of the city as follows: $72 \%$ Seasonal Semideciduous Forest, 19\% Grassland, 8\% Eucalyptus, and $1 \%$ Cerrado.

According to the Köppen classification, the climate of the city is type Cwa - temperate humid with summer rains and dry winter. According to climatological normal data of the National Institute of Meteorology from 1981 to 2010, the average annual rainfall in Florestal city is $1,393 \mathrm{~mm}$, with minimum and maximum average temperatures of 14.4 and $28.9^{\circ} \mathrm{C}$, respectively, and average annual relative humidity of $64 \%$.

\section{Floristic survey and phytosociological analysis}

Trunk diameter at breast height (DBH at $1.30 \mathrm{~m}$ from the ground) was measured, and regenerating tree individuals with $\mathrm{DBH} \geq 5 \mathrm{~cm}$ found in the understory of eucalyptus plantation were botanically identified. Sampling was random and consisted of seven plots of $100 \mathrm{~m}^{2}(5 \times 20 \mathrm{~m})$, as proposed by Rodrigues et al. (2013). Sampling sufficiency was verified by the species accumulation curve (Freitas \& Magalhães, 2012).

Species were identified in the field, with their identification being confirmed by consulting the bibliography (Lorenzi, 2016; Carvalho, 2014). The classification system adopted was that proposed by the Angiosperm Phylogeny Group III, being verified in the Missouri Botanical Garden database via virtual access (www.tropicos.org).
The following phytosociological parameters were calculated: frequency, density, dominance, and importance value (Freitas \& Magalhães, 2012). Species were classified according to dispersal syndrome (autochory, zoochory, and anemochory) and ecological group (pioneer, early secondary, late secondary, and climax) (Vieira, 2016; Barbosa, 2017).

\section{Results and Discussion}

A total of 109 tree individuals with $\mathrm{DBH} \geq 5 \mathrm{~cm}$ were found in natural regeneration under $C$. citriodora plantation, corresponding to 28 species belonging to 12 botanical families, of which Fabacea and Annonaceae stood out with $46 \%$ of the total (Table 1).

The most phytosociologically important species (43\%) in the studied area were, respectively: Psidium sp. ('araça'); Schefflera macrocarpa (Cham. \& Schltdl.) Frodin ('mandioqueira'); Pera glabrata (Schott) Poepp. ex Baill. ('folha-miuda'); Astronium fraxinifolium Schott \& Spreng. ('gonçalo-alves'); Matayba guianensis Aubl. ('camboata'); and Plathymenia reticulata Benth. ('vinhatico').

The species found are typical of the Seasonal Semideciduous Forest of the Atlantic Forest biome (Scolforo, Mello, \& Silva, 2008; Barbosa, 2017), and occur in the region of Florestal city, Minas Gerais, Brazil (Vieira, 2016).

It is noteworthy that each specific ecological condition, in terms of climate, soil, relief, landscape, remnant fragments, etc., provides a unique trajectory of natural regeneration and stochastic forest succession and, consequently, of floristic composition and phytosociological importance of species (Gandolfi, 2017).

The richness of natural regeneration under eucalyptus plantation in Brazil can reach values of 30 to 140 native tree species (Onofre, Engel, \& Cassola, 2010). Surveys include 79 families, 292 genera, and 721 native species already found in the understory of eucalyptus plantations in Brazil (Costa, 2018).

The density and diversity of natural regeneration under commonly planted homogeneous forests vary as a function of canopy density and light availability in the understory, age and species of the planted forest, distance and quality of surrounding native vegetation remnants, management of planted forest, and the history of use of the area (Viani et al., 2010).

The estimated total basal area and density of the regenerants found under C. citriodora planting were, respectively, $23.00 \mathrm{~m}^{2} \mathrm{ha}^{-1}$ and 1,557 individuals $\mathrm{ha}^{-1}$. According to Rodrigues, Isernhagem, and Brancalion (2009), for forest restoration purposes in the Atlantic Forest biome, the minimum required density of regenerants is 1,000 individuals $\mathrm{ha}^{-1}$, regardless of the DBH class.

Costa (2018) found 2,140 individuals ha ${ }^{-1}$ with $\mathrm{DBH} \geq 2.5$ $\mathrm{cm}$ and basal area of $11.04 \mathrm{~m}^{2} \mathrm{ha}^{-1}$ in natural regeneration under Eucalyptus grandis Hill ex Maiden planted 60 years ago. Compared to the density of 1,557 individuals $\mathrm{ha}^{-1}$ observed in the present study, the higher density found by that author is certainly due to the sampling being performed on regenerating individuals with $\mathrm{DBH} \geq 2.5 \mathrm{~cm}$. On the other hand, the basal area represents about $50 \%$ of that of the present study, indicating that regenerating individuals were smaller, particularly in trunk diameter. 
The distribution of regenerating species in ecological groups in the present study was as follows: $35 \%$ pioneer, $40 \%$ early secondary, $18 \%$ late secondary, and $7 \%$ climax. Phytosociological parameters confirm the overwhelming dominance of pioneer and early secondary species in terms of spatial distribution (frequency), density of individuals, basal area (dominance), and importance value in the plant community from an approach in terms of horizontal structure (Table 2).
The dominance of pioneer and early secondary species indicates that natural regeneration is in the early stages of forest succession (Brancalion et al., 2015). On the other hand, the presence of species of all ecological groups in natural regeneration, from heliophilic pioneers to shade-tolerant late secondary, signals the possibility of progression of the successional process over time (Gandolfi, 2017), which will occur from senescence or intentional felling of eucalyptus trees still present in the area (Isernhagen et al., 2009).

Table 1. Species and families found in natural regeneration under a planted forest of Corymbia citriodora at the Federal University of Viçosa - Campus Florestal, Florestal city, Minas Gerais, Brazil, and their ecological aspects.

\begin{tabular}{|c|c|c|c|c|c|c|c|c|}
\hline Family & Popular Name & Scientific Name & EG & DS & $\mathrm{RF}$ & RDe & RDo & IVI \\
\hline Anacardiaceae & Gonçalo-alves & Astronium fraxinifolium Schott \& Spreng. & ES & ANE & 6.1 & 5.5 & 7.7 & 6.4 \\
\hline Annonaceae & Pindaíba & Xylopia sp. & $\mathrm{P}$ & $\mathrm{ZOO}$ & 6.1 & 5.5 & 5.0 & 5.5 \\
\hline Annonaceae & Araticunzinho & Annona sp & $\mathrm{P}$ & $\mathrm{ZOO}$ & 3.0 & 5.5 & 5.7 & 4.7 \\
\hline Annonaceae & Araticum & Annona sp. & $\mathrm{P}$ & $\mathrm{ZOO}$ & 3.0 & 1.8 & 3.5 & 2.8 \\
\hline Annonaceae & $\begin{array}{l}\text { Pindaíba- } \\
\text { vermelha }\end{array}$ & Xylopia brasiliensis Spreng. & LS & $\mathrm{ZOO}$ & 3.0 & 1.8 & 0.3 & 1.7 \\
\hline Araliaceae & Mandioqueira & $\begin{array}{c}\text { Schefflera macrocarpa (Cham. \& Schltdl.) } \\
\text { Frodin }\end{array}$ & $\mathrm{P}$ & $\mathrm{ZOO}$ & 6.1 & 7.3 & 8.0 & 7.1 \\
\hline Arecaceae & Jerivá & Syagrus romanzoffiana (Cham.) Glassman & $\mathrm{P}$ & $\mathrm{ZOO}$ & 3.0 & 1.8 & 0.2 & 1.7 \\
\hline Bignoniaceae & Ipê-amarelo & Handroanthus serratifolius (Vahl) S.Grose & LS & ANE & 4.5 & 4.6 & 4.7 & 4.6 \\
\hline Bignoniaceae & Ipê-caraíba & Handroanthus caraiba (Mart.) Mattos & LS & ANE & 1.5 & 0.9 & 0.9 & 1.1 \\
\hline Fabaceae & Óleo-copaíba & Copaifera langsdorffii Desf. & $\mathrm{C}$ & $\mathrm{ZOO}$ & 1.5 & 0.9 & 8.6 & 3.6 \\
\hline Fabaceae & Jacarandá-caviúna & Dalbergia villosa (Benth.) Benth. & $\mathrm{P}$ & ANE & 3.0 & 1.8 & 1.3 & 2.07 \\
\hline Fabaceae & Sucupira-preta & Bowdichia virgilioides Kunth & $\mathrm{P}$ & ANE & 1.5 & 0.9 & 2.4 & 1.6 \\
\hline Fabaceae & Bico-de-pato & Machaerium nyctitans (Vell.) Benth & $\mathrm{P}$ & ANE & 1.5 & 0.9 & 0.2 & 0.9 \\
\hline Fabaceae & Vinhático & Plathymenia reticulata Benth. & ES & ANE & 3.0 & 2.7 & 12.7 & 6.1 \\
\hline Fabaceae & Jacarandá & Machaerium sp. & ES & ANE & 4.5 & 2.7 & 3.9 & 3.7 \\
\hline Fabaceae & Farinha-seca & Peltophorum dubium (Spreng.) Taub. & $\mathrm{P}$ & AUT & 3.0 & 1.8 & 1.7 & 2.2 \\
\hline Fabaceae & Angico-branco & Anadenanthera colubrina (Vell.) Brenan & ES & ANE & 1.5 & 0.9 & 2.4 & 1.6 \\
\hline Fabaceae & Angico-vermelho & Anadenanthera macrocarpa (Benth.) Brenan. & ES & ANE & 1.5 & 1.8 & 0.7 & 1.4 \\
\hline Lauraceae & Canela & Ocotea $\mathrm{sp}$ & LS & $\mathrm{ZOO}$ & 3.0 & 5.5 & 1.3 & 3.3 \\
\hline Melastomataceae & Pau-prego & Mouriri glazioviana Cogn. & $\mathrm{C}$ & $\mathrm{ZOO}$ & 4.5 & 2.7 & 1.8 & 3.0 \\
\hline Melastomataceae & e Casca-de-arroz & Miconia $\mathrm{sp}$ & LS & $\mathrm{ZOO}$ & 1.5 & 0.9 & 0.6 & 1.0 \\
\hline Meliaceae & $\begin{array}{c}\text { Calcanhar-de- } \\
\text { cutia }\end{array}$ & Guarea sp. & ES & $\mathrm{ZOO}$ & 1.5 & 3.7 & 0.8 & 2.0 \\
\hline Meliaceae & Cedro & Cedrela fissilis Vell. & ES & ANE & 1.5 & 0.9 & 3.3 & 1.9 \\
\hline Myrtaceae & Araçá & Psidium sp. & ES & $\mathrm{ZOO}$ & 4.5 & 14.7 & 11.8 & 10.3 \\
\hline Myrtaceae & Piúna & Myrcia sp. & ES & $\mathrm{ZOO}$ & 7.6 & 6.4 & 1.1 & 5.0 \\
\hline Peraceae & Folha-miúda & Pera glabrata (Schott) Poepp. ex Baill. & $\mathrm{P}$ & $\mathrm{ZOO}$ & 9.1 & 7.3 & 4.2 & 6.9 \\
\hline Sapindaceae & Camboatá & Matayba guianensis Aubl. & ES & $\mathrm{ZOO}$ & 7.6 & 7.3 & 3.4 & 6.1 \\
\hline Sapindaceae & Camboatá-de-rego & Matayba elaeagnoides Radlk. & ES & $\mathrm{ZOO}$ & 1.5 & 0.9 & 1.4 & 1.3 \\
\hline Total & & & & & $100 \%$ & $100 \%$ & $100 \%$ & $100 \%$ \\
\hline
\end{tabular}

Ecological groups (EG) - pioneer (P), early secondary (ES), late secondary (LS), and climax (C); dispersion syndromes (DS) - zoochory (ZOO), anemochory (ANE), and autochory (AUT); relative frequency (RF), relative density (RDe), relative dominance (RDo), and importance value index (IVI).

The seed dispersal syndromes of the regenerating species were as follows: $40 \%$ anemochoric, $57 \%$ zoochoric, and $3 \%$ autochoric. According to Carvalho (2010), most tropical tree species present zoochoric dispersion, indicating the importance of fauna, ecological corridors, and landscape permeability in both seed dispersal and area colonization (Arana \& Almirante, 2007).

Costa (2018) found 68.8\% nonpioneer (late secondary and climax) and $81.1 \%$ zoochoric species among native regenerants in the understory of $E$. grandis planted about 60 years ago.

The dominance of zoochoric species in natural regeneration attests that eucalyptus, despite being an exotic species in Brazil, acts to attract fauna (Costa, 2018) and mainly as a perch for avifauna.

Torresan, Vital, Araujo, and Cola (2011) recorded 53 bird species in a eucalyptus forestry area, being distributed in 23 families and 11 orders. One of the desirable characteristics of species planted during forest restoration is certainly their attractiveness to fauna, favoring the colonization of the area 
by regional native species (Carneiro \& Rodrigues, 2007).

Table 2. Values of phytosociological parameters by ecological group of regenerating species in the understory of a planted forest of Corymbia citriodora at the Federal University of Viçosa - Campus Florestal, Florestal city, Minas Gerais, Brazil.

\begin{tabular}{ccccc}
\hline Ecological Group & RF & RDe & RDo & IVI \\
\hline Pioneer & 3.4 & 33.0 & 30.6 & 33.3 \\
Early Secondary & $43 ., 9$ & 49.5 & 51.1 & 48.2 \\
Late Secondary & 13.6 & 13.8 & 7.9 & 11.8 \\
Climax & 6.1 & 3.7 & 10.4 & 6.7 \\
\hline Total & $100 \%$ & $100 \%$ & $100 \%$ & $100 \%$ \\
\hline
\end{tabular}

RF - Relative frequency, RDe - Relative density, RDo - Relative
dominance, IVI - Importance value index.

On the other hand, the significant presence of winddispersed regenerants in the study area can be explained by the proximity (about $20 \mathrm{~m}$ ) of a well-preserved Semideciduous Seasonal Forest fragment, enabling the contribution of anemochoric propagules (Viani et al., 2010).

Considering the dispersal syndromes by ecological group, there is a decrease in anemochory among late species, while zoochory is present among all ecological groups (Table 3). This fact reinforces the role of fauna in the reintroduction of biodiversity throughout forest restoration (Carnevale \& Montagnini, 2002).

Table 3. Ecological groups and dispersal syndromes of regenerating species found in the understory of a planted forest of Corymbia citriodora at the Federal University of Viçosa - Campus Florestal, Florestal city, Minas Gerais, Brazil.

\begin{tabular}{cccc}
\hline \multirow{2}{*}{ Ecological Group } & \multicolumn{3}{c}{ Dispersal Syndrome } \\
\cline { 2 - 4 } & Autochory & Anemochory & Zoochory \\
\hline Pioneer & 0 & 30 & 38 \\
Early Secondary & 100 & 60 & 31 \\
Late Secondary & 0 & 10 & 19 \\
Climax & 0 & 0 & 12 \\
\hline Total & $100 \%$ & $100 \%$ & $100 \%$ \\
\hline
\end{tabular}

The intensity of natural regeneration will likely depend on local conditions, defined by initial planting spacing, level of shading and invasive exclusion (Modna, Durigan, \& Vital, 2010), and surrounding conditions associated with presence, distance, and conservation status of native vegetation remnants, besides the permeability of the surrounding landscape (Souza Leite et al., 2013; Almeida, 2016).

In addition to providing the shade and habitat required for the suppression of unwanted invasive species and the establishment of native tree species (Carnus et al., 2006; Carneiro \& Rodrigues, 2007), planted forests should also be attractive to fauna (Torresan et al., 2011), enhancing the external contribution of propagules via zoochory (Brancalion et al., 2015; Gandolfi, 2017).

For homogeneous planted forests to play the role of pioneers and facilitators in restoring native forests (Modna et al., 2010), they must be managed in such a way as to preserve the regeneration of native vegetation present in their understory (Viani et al., 2010).

Planted exotic trees should be gradually removed by selective felling of single trees or tree lines, maintaining the forest structure and mitigating damage to regeneration. Another possibility would be through ringing and poisoning, causing the death of standing trees, but maintaining perches and seed dispersal by birds (Isernhagen et al., 2009).

\section{Conclusions}

The $C$. citriodora forest provided natural regeneration with high density of individuals and species (mostly pioneer or early secondary) of the Atlantic Forest in its understory, with anemochoric or zoochoric dispersal syndromes.

Natural regeneration occurred due to the canopy structure and the creation of a forest habitat by $C$. citriodora trees, providing conditions for the attraction and establishment of native tree species in its understory, coming from preserved forest remnants existing around the studied area.

\section{References}

Almeida, D. S. (2016). (3a ed.) Recuperação ambiental da mata atlântica. SciELO-Editus, Editora da UESC.

Arana, A. R. A., \& Almirante, M. F. (2007). A importância do corredor ecológico: um estudo sobre Parque Estadual "Morro do Diabo" em Teodoro Sampaio-SP. Geografia, 16(1), 143-168. doi:10.5433/2447$1747.2007 \mathrm{v} 16 \mathrm{n} 1 \mathrm{p} 143$

Barbosa, L. M. (org.) (2017). Lista de espécies indicadas para restauração ecológica para diversas regiões do estado de São Paulo. São Paulo: Secretaria de Meio Ambiente. Instituto de Botânica.

Brancalion, P.H.S., Gandolfi, S., \& Rodrigues, R.R. (2015). Restauração florestal. São Paulo: Oficina de Textos.

Carneiro, P. H. M., \& Rodrigues, R. R. (2007). Management of monospecific commercial reforestations for the forest restoration of native species with high diversity. High diversity forest restoration in degraded areas: Methods and projects in Brazil. (pp. 129-144) New York: Nova Science Publishers.

Carnevale, N. J., \& Montagnini, F. (2002). Facilitating regeneration of secondary forests with the use of mixed and pure plantations of indigenous tree species. Forest Ecology and Management, 163(1-3), 217227. doi:10.1016/S0378-1127(01)00581-3

Carnus, J. M., Parrotta, J., Brockerhoff, E., Arbez, M., Jactel, H., Kremer, A., ... \& Walters, B. (2006). Planted forests and biodiversity. Journal of Forestry, 104(2), 65-77. doi:10.1093/jof/104.2.65

Carvalho, P. E. R. (2014) Espécies arbóreas brasileiras. Brasília: Embrapa Informação Tecnológica.

Carvalho, F. A. (2010). Síndromes de dispersão de espécies arbóreas de florestas ombrófilas submontanas do estado do Rio de Janeiro. Revista Árvore, 34(6), 1017-1023. doi: 10.1590/S0100-67622010000600007

Costa, J. P. (2018). Regeneração natural no sub-bosque de eucaliptal no Parque Estadual das Fontes do Ipiranga, São Paulo, SP (Tese de Mestrado). Instituto de Botânica, Secretaria de Estado do Meio Ambiente, São Paulo.

Freitas, W. K. D., \& Magalhães, L. M. S. (2012). Métodos e parâmetros para estudo da vegetação com ênfase no estrato arbóreo. Floresta e Ambiente, 19(4), 520-539. doi: 10.4322/floram.2012.054

Gandolfi, S. (2017). Uma teoria sobre o processo de restauração ecológica de florestas tropicais e subtropicais: proposta e aplicação. (Tese de Livre Docência). Escola Superior de Agricultura "Luiz de Queiroz", Universidade de São Paulo, Piracicaba, São Paulo.

Isernhagen, I., Rodrigues, R. R., Nave, A. G., \& Gandolfi, S. (2009). Diagnóstico ambiental das áreas a serem restauradas visando a definição de metodologias de restauração florestal. Pacto para restauração da Mata Atlântica: referencial dos conceitos e ações de restauração florestal (pp. 87-127). São Paulo: LERF/ESALQ, Instituto BioAtlântica.

Lorenzi, H. (2016). Árvores brasileiras: manual de identificação e cultivo de plantas arbóreas nativas do Brasil. (7a ed.) Nova Odessa, Plantarum (3v.).

Modna, D., Durigan, G., \& Vital, M. V. C. (2010). Pinus elliottii Engelm as 
facilitator of riparian forest regeneration in savanna region, Assis, SP, Brazil. Scientia Forestalis, 38(85), 73-83.

Onofre, F. F., Engel, V. L., \& Cassola, H. (2010). Regeneração natural de espécies da Mata Atlântica em sub-bosque de Eucalyptus saligna Smith. em uma antiga unidade de produção florestal no Parque das Neblinas, Bertioga, SP. Scientia Forestalis, 38(85), 39-52.

Ribeiro, M. C., Metzger, J. P., Martensen, A. C., Ponzoni, F. J., \& Hirota, M. M. (2009). The Brazilian Atlantic Forest: How much is left, and how is there maining forest distributed? Implications for conservation. Biological Conservation, 142(6), 1141-1153. doi:10.1016/j.biocon.2009.02.021

Rodrigues, R. R., A. Padovezi, A., Turini Farah, F., Couto Garcia, L., Dias Sanglade, L., Brancalion, P.H.S., ... \& Egydio Barreto, T. (2013). Protocolo de monitoramento para programas e projetos de restauração florestal. São Paulo: Ed. R.A. Gorne Viani.

Rodrigues, R. R., Isernhagem, I., \& Brancalion, P. H. S. (2009). Pacto pela restauração da mata atlântica: referencial dos conceitos e ações de restauração florestal. São Paulo: LERF/ESALQ, Instituto BioAtlântica.

Scolforo, J. R., Mello, J. M., \& Silva, C. P. C.(2008). Inventário florestal de Minas Gerais: Floresta Estacional Semidecidual e Ombrófila -florística, estrutura, diversidade, similaridade, distribuição diamétrica e de altura, volumetria, tendências de crescimento e áreas. aptas para manejo florestal. Lavras: Editora UFLA.

Souza Leite, M., Tambosi, L. R., Romitelli, I., \& Metzger, J. P. (2013). Landscape ecology perspective in restoration projects for biodiversity conservation: a review. Natureza \& Conservação, 11, 108-118. doi:10.4322/natcon.2013.019

Torresan, F., Vital, D., Araujo, L. S., \& Cola, M. D. S. (2011). Diversidade de espécies de aves em silvicultura de eucalipto. Brasília: Embrapa Territorial, Boletim de Pesquisa e Desenvolvimento (INFOTECA-E).

https://ainfo.cnptia.embrapa.br/digital/bitstream/item/56791/1/015-11.pdf

Viani, R.A.G., Durigan, G., \& Melo, A.C.G.D. (2010). A regeneração natural sob plantações florestais: desertos verdes ou redutos de biodiversidade? $\begin{array}{llr}\text { Ciência } & \text { Florestal, } & \text { 20(3), }\end{array}$ https://periodicos.ufsm.br/cienciaflorestal/article/view/2067/1246

Vieira, L. M. G. (2016). Efeito de borda na estrutura de fragmentos de floresta estacional semidecidual de diferentes tamanhos na bacia do rio Paraopeba, MG. 2016. (Dissertação de Mestrado) Universidade Federal de Viçosa, Florestal, Minas Gerais.

License: Creative Commons CC BY 4.0

This article was published with open access for distribution under the terms of the Creative Commons Attribution License, which allows unrestricted use, distribution, and reproduction in any medium, provided the original work is properly cited. 